3 Rost van T onningen M , G arbis H, Reuvers M. Ecstasy exposure during pregnancy. Teratology 1998; 58: 33.

4 van T onningen-van D riel M M , G arbis Berkvens JM, Reuvers L odewijks WB. Zwangerschapsuitkomst na ecstacygebruik: 43 gevallen gevolgd door de T eratologie Informatie Service van het RIVM . N ed Tijdschr G eneeskd 1999; 143: 27-31.

5 Schardein JL. Chemically induced birth defects, 2nd edn. N ew York, M arcel Dekker, 1993.

National Teratology Information Service, Regional Drug and Therapeutics Centre, Wolfson Unit, Newcastle upon Tyne NE2 4HH, UK (P R McElhattorphD, C Evans BSc, K R Pughessc,

S H L Thomas MD); and Scottish Poisons Information Bureau, Royal Edinburgh NHS Trust, Edinburgh, EH3 9YW, UK (D N BatemanMD)

Correspondence to: Dr P R McElhatton

(e-mail: Patricia.McElhatton@ncl.ac.uk)

\section{Aetiological parallel between tonsillar and anogenital squamous-cell carcinomas}

Morten Frisch, Robert J Biggar

Patients with human papillomavirus (HPV)-associated anogenital cancers had a $4 \cdot 3$-fold increased risk of tonsillar squamous-cell carcinoma. These cancer types also have histopathological and molecular biological similarities. Thus HPV may be aetiologically important in tonsillar carcinogenesis.

Similarities between mucosal linings at anogenital and oral sites make plausible a role for human papillomaviruses (H PV) in oral carcinogenesis. HPV are found in most anogenital squamous-cell carcinomas (SCC), but usually in less than $20 \%$ of oral cancers. T onsillar SC C, however, is more likely than other oral cancers to be HPV positive. ${ }^{1}$ We studied patients with HPV-associated anogenital SCC to test the hypothesis that these patients are at increased risk of tonsillar SCC.

U sing Surveillance, Epidemiology, and End Results data from 1973 to 1994, we identified 72066 individuals whose first cancer was an HPV-associated anogenital SCC (or cervical SCC in situ) and 422023 with invasive HPVunrelated first cancers of the colon, stomach, or breast (table 1). Person-years were counted from 1 month after the initial diagnosis until a diagnosis of one of the studied invasive SCC (tonsillar, other oral, cervical, vulvar/vaginal, or anal), death, or Jan 1, 1995, whichever came first. Population incidence rates for these SCC were calculated for strata of sex, race, and 5-year age and calendar periods. The expected number of a particular SCC was calculated as the sum of stratum-specific products of person-years and population incidence. Ratios of observed-to-expected SC C served as measures of relative risk. We compared relative risks of tonsillar SCC and of other oral SC C after anogenital $\mathrm{SCC} .^{2}$
Among patients with anogenital SCC, risks of SCCS at other anogenital sites were high (209 observed, relative risk 3.6 [95\% C। 3.1-4.1]; table 2). The risk of tonsillar SC C was similarly increased. All three cases of tonsillar SC C after anal

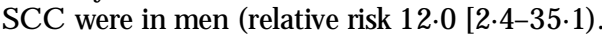

Other oral SC C also occurred in excess, though the relative risk (2.3 [1.7-3.0]) was significantly lower than that for tonsillar SCC ( $p=0.013$, one-sided). Among patients with HPV-unrelated cancers, relative risks were close to $1 \cdot 0$, although slightly low for cervical SCC.

This study suggests a strong link between tonsillar and anogenital SCC. H PV may be a common aetiological factor. T obacco, a major risk factor for oral cancers, is also linked aetiologically to anogenital SC C and may have contributed to the association. $\mathrm{H}$ owever, the finding that the relative risk was significantly higher for tonsillar SCC than for other oral SC C supports a role for HPV in the aetiology of tonsillar SCC. Although based on small numbers, the highest relative risk for tonsillar SCC was in patients with anal SCC, a cancer common among homosexual men. All three tonsillar cancers after anal SCC were in unmarried or divorced men. U nprotected orogenital sex with an infected partner may result in transmission of H PV to the oral cavity. There are no specific published data on sexual behaviours of patients with tonsillar cancer, but one study suggested an association between active oral sex and risk of oral cancer positive for H PV-16 DN A, of which tonsillar SCC was the most common type. ${ }^{3} \mathrm{~T}$ he role of the immune system in tonsillar carcinogenesis is unknown. $\mathrm{O}$ ther H PV-associated cancers occur in excess among patients with HIV infection and AIDS and among patients with transplantation-related immunosuppression. Tonsillar SCC has been reported in young transplant patients. ${ }^{4}$ The increasing incidence of tonsillar SC C in young U S men, but not women (unpublished) may reflect an association with HIV-related immunosuppression.

The tonsillar crypt epithelium, believed to favour the capture and processing of antigens, may facilitate viral access to basal mucosal cells. This idea accords with the suggestion that H PV associated tonsillar SCCs originate from the crypts, whereas HPV-unrelated SCC emerge from the tonsillar surface. ${ }^{5}$

This study was supported partly by the $D$ anish $M$ edical Research Council.

1 Paz IB, Cook N , Odom-M aryon T, X ieY, Wilczynski SP. H uman papillomavirus (HPV) in head and neck cancer: an association of H PV 16 with squamous cell carcinoma of W aldeyer's tonsillar ring. Cancer 1997; 79: 595-604.

2 Brownlee K A. Statistical theory and methodology in science and engineering. $\mathrm{N}$ ew $\mathrm{Y}$ ork: Wiley, 1967: 183-85.

3 Schwartz SM, Daling JR, D oody D R, et al. O ral cancer risk in relation to sexual history and evidence of human papillomavirus infection. J N atl Cancer Inst 1998; 90: 1626-36.

4 Swoboda A, Fabrizii V. T onsillar carcinoma in a renal graft recipient treated with cyclosporine A. Clin N ephrol 1993; 39: 272-74.

5 Wilczynski SP, L in BT, X ie Y, Paz IB. D etection of human papillomavirus DNA and oncoprotein overexpression are associated with distinct morphological patterns of tonsillar squamous cell carcinoma. Am J Pathol 1998; 152: 145-56.

\begin{tabular}{|c|c|c|c|c|}
\hline Initial cancer & ICD-02 code topography + histology & Number of patients & Median age (years) & Person-years of follow-up \\
\hline $\begin{array}{l}\text { HPV-associated anogenital SCC } \\
\text { Cervical SCC } \\
\text { Cervical SCC in situ } \\
\text { Vulvar/ vaginal SCC } \\
\text { Anal SCC* } \\
\text { Total }\end{array}$ & $\begin{array}{l}\text { C530-C539+80503-80763 } \\
\text { C530-C539+80502-80762 } \\
\text { C510-C529 + 80503-80763 } \\
\text { C209-C218 + 80503-80763, 80943, 81203-80243 }\end{array}$ & $\begin{array}{r}18586 \\
46093 \\
4155 \\
3232 \\
72066\end{array}$ & $\begin{array}{l}50 \\
31 \\
70 \\
63\end{array}$ & $\begin{array}{r}120535 \\
341713 \\
21907 \\
16522 \\
500677\end{array}$ \\
\hline $\begin{array}{l}\text { HPV-unrelated cancer } \\
\text { Colon cancer* } \\
\text { Stomach cancer* } \\
\text { Breast cancer (women) } \\
\text { Total }\end{array}$ & $\begin{array}{l}\text { C180-C189 + any } \\
\text { C160-C169 + any } \\
\text { C500-C509 + any }\end{array}$ & $\begin{array}{r}145994 \\
37104 \\
238925 \\
422023\end{array}$ & $\begin{array}{l}71 \\
69 \\
62\end{array}$ & $\begin{array}{r}668614 \\
78915 \\
1490875 \\
2238404\end{array}$ \\
\hline
\end{tabular}

ICD-02=International Classification of Diseases for Oncology, 2nd edn, 1990.

* Proportions of women were $66 \%, 53 \%$, and $39 \%$ among patients with initial anal SCC, colon cancer, and stomach cancer, respectively.

Table 1: Cohorts of patients followed up for tonsillar SCC, other oral SCC, and anogenital SCC after initial HPV-associated and HPVunrelated cancers, SEER 1973-94 


\begin{tabular}{|c|c|c|c|c|c|c|c|c|c|c|}
\hline \multirow[t]{3}{*}{ Initial cancer } & \multicolumn{10}{|c|}{ Second cancer* } \\
\hline & \multicolumn{2}{|c|}{ Tonsillar SCC } & \multicolumn{2}{|l|}{ Other oral SCC } & \multicolumn{2}{|l|}{ Cervical SCC } & \multicolumn{2}{|c|}{ Vulvar/ vaginal SCC } & \multicolumn{2}{|l|}{ Anal SCC } \\
\hline & O/E & $\operatorname{RR}(95 \% \mathrm{Cl})$ & O/E & $\operatorname{RR}(95 \% \mathrm{Cl})$ & O/E & $\operatorname{RR}(95 \% \mathrm{Cl})$ & O/E & $\operatorname{RR}(95 \% \mathrm{Cl})$ & O/E & $\operatorname{RR}(95 \% \mathrm{Cl})$ \\
\hline \multicolumn{11}{|l|}{$\overline{\text { HPV-associated anogenital SCC }}$} \\
\hline $\begin{array}{l}\text { Cervical SCC } \\
\text { Cervical SCC (in-situ) }\end{array}$ & $\begin{array}{l}9 / 1 \cdot 7 \\
7 / 2 \cdot 0\end{array}$ & $\begin{array}{r}5 \cdot 2(2 \cdot 4-10 \cdot 0) \\
3 \cdot 5(1 \cdot 4-7 \cdot 3)\end{array}$ & $\begin{array}{l}19 / 9 \cdot 0 \\
17 / 9 \cdot 6\end{array}$ & $\begin{array}{c}2 \cdot 0(1 \cdot 3-3 \cdot 3) \\
1 \cdot 8(1 \cdot 0-2 \cdot 8)\end{array}$ & $\begin{array}{l}. " \\
52 / 36.8\end{array}$ & ${ }^{\prime \prime} 1.4(1.1-1.9)$ & $\begin{array}{l}54 / 4 \cdot 8 \\
53 / 5 \cdot 4\end{array}$ & $\begin{array}{l}11 \cdot 2(8 \cdot 4-14 \cdot 7) \\
9 \cdot 8(7 \cdot 3-12 \cdot 8)\end{array}$ & $\begin{array}{l}10 / 2.5 \\
14 / 3.0\end{array}$ & $\begin{array}{l}4 \cdot 0(1 \cdot 9-7 \cdot 3) \\
4 \cdot 7(2 \cdot 6-8 \cdot 0)\end{array}$ \\
\hline Vulvar/ vaginal SCC & $1 / 0.4$ & $2 \cdot 5(0-13 \cdot 7)$ & $9 / 2.8$ & $3 \cdot 3(1 \cdot 5-6 \cdot 2)$ & $9 / 3.0$ & $3.0(1.4-5 \cdot 8)$ & .. & .. & $8 / 0.8$ & $10 \cdot 4(4 \cdot 5-20 \cdot 5)$ \\
\hline Anal SCC & $3 / 0.5$ & $6 \cdot 1(1 \cdot 2-17 \cdot 9)$ & $10 / 2 \cdot 7$ & $3 \cdot 7(1 \cdot 8-6 \cdot 9)$ & $1 / 1.5$ & $0.7(0-3.6)$ & $8 / 0.8$ & $9 \cdot 6(4 \cdot 1-18 \cdot 9)$ & .. & .. \\
\hline Total & $20 / 4 \cdot 6$ & $4 \cdot 3(2 \cdot 7-6 \cdot 7)$ & $55 / 24 \cdot 1$ & $2 \cdot 3(1 \cdot 7-3 \cdot 0)$ & $62 / 41 \cdot 3$ & $1.5(1.2-1.9)$ & $115 / 11 \cdot 0$ & $10 \cdot 5(8 \cdot 6-12 \cdot 5)$ & $32 / 6 \cdot 3$ & $5 \cdot 1(3 \cdot 5-7 \cdot 2)$ \\
\hline \multicolumn{11}{|l|}{ HPV-unrelated cancers } \\
\hline Colon cancer & $17 / 22 \cdot 8$ & $0.7(0.4-1.2)$ & $149 / 135 \cdot 1$ & $1 \cdot 1(0 \cdot 9-1 \cdot 3)$ & $45 / 49 \cdot 0$ & $0.9(0.7-1.2)$ & $35 / 34.6$ & $1.0(0.7-1 \cdot 4)$ & $29 / 20 \cdot 2$ & $1 \cdot 4(1 \cdot 0-2 \cdot 1)$ \\
\hline Stomach cancer & $3 / 3 \cdot 0$ & $1.0(0.2-2.9)$ & $15 / 16 \cdot 4$ & $0.9(0.5-1.5)$ & $2 / 5 \cdot 2$ & $0.4(0-1.4)$ & $6 / 2.9$ & $2 \cdot 1(0.8-4 \cdot 5)$ & $3 / 2 \cdot 0$ & $1 \cdot 5(0 \cdot 3-4 \cdot 3)$ \\
\hline Breast cancer (women) & $26 / 28 \cdot 7$ & $0.9(0.6-1.3)$ & $189 / 171 \cdot 2$ & $1 \cdot 1(1 \cdot 0-1 \cdot 3)$ & $144 / 196 \cdot 1$ & $0.7(0.6-0.9)$ & $79 / 97 \cdot 8$ & $0.8(0.6-1.0)$ & $42 / 48 \cdot 2$ & $0.9(0.6-1.2)$ \\
\hline Total & $46 / 54 \cdot 5$ & $0.8(0.6-1.1)$ & $353 / 322 \cdot 7$ & $1 \cdot 1(1 \cdot 0-1 \cdot 2)$ & $191 / 250 \cdot 3$ & $0.8(0.7-0.9)$ & $120 / 135 \cdot 3$ & $0.9(0 \cdot 7-1 \cdot 1)$ & $74 / 70 \cdot 4$ & $1 \cdot 1(0 \cdot 8-1 \cdot 3)$ \\
\hline
\end{tabular}

$0=0$ bserved; $E=$ expected; $R R=$ relative risk

$\star \mid C D-02$ codes used to define observed and expected oral cancers comprise C090-C099+80503-80763, 80943, 81203-81243 (tonsillae SCC) and C019-C069, C100-C109 + $80503-80763,80943,81203-81243$ (other oral SCC). Observed and expected invasive cervical, vulvar/ vaginal, and anal SCC meet the topography and histology criteria for corresponding cohorts in table 1.

Table 2: Tonsillar SCC, other oral SCC, and anogenital SCC after initial HPV-associated cervical, vulvar/ vaginal, and anal SCC and HPV-unrelated cancers of colon, stomach, and breast, SEER 1973-94

National Cancer Institute, Division of Cancer Epidemiology and Genetics, Viral Epidemiology Branch, B ethesda, MD, USA

(M Frischmd, R J BiggarmD); and Department of Epidemiology Research, Danish Epidemiology Science Centre, Statens Serum Institut, Copenhagen, Denmark (M Frisch)

Correspondence to: Dr Morten Frisch, Viral Epidemiology Branch, Division of Cancer Epidemiology and Genetics, National Cancer Institute, 6120 Executive Blvd, Room 8009, Bethesda, 20852 MD, USA

(e-mail: frischm@mail.nih.gov)

\section{Clopidogrel and membranous nephropathy}

U Tholl, M Anlauf, U Helmchen

Membranous nephropathy with nephrotic syndrome occurred in a patient with anterior myocardial infarction 2 months after the start of clopidogrel treatment. Sensitisation by prior treatment with ticlopidine is discussed.

The thienopyridine derivatives ticlopidine and clopidogrel are specific and potent inhibitors of platelet aggregation that are metabolised in the liver into active substances. The CAPRIE study showed that clopidogrel is superior to aspirin in patients with ischaemic risk, ${ }^{2}$ and clopidogrel was subsequently approved in many countries for secondary prevention of myocardial infarction and ischaemic stroke in patients with symptomatic atherosclerotic vascular disease. Severe adverse events have been associated with ticlopidine therapy: acute renal failure ${ }^{3,4}$ and acute interstitial nephritis ${ }^{5}$ have been reported. The occurrence of severe side-effects is thought to be lower with clopidrogrel than with ticlopidine.

We report a 46-year-old man who had an anterior myocardial infarction in $\mathrm{M}$ arch, 1997. After streptokinase lysis, stenosis of the right coronary artery was detected by coronary angiography. 4 days later, percutaneous transluminal angioplasty of this stenosis was carried out, and a multilink stent was positioned. $500 \mathrm{mg} /$ day ticlopidine and $100 \mathrm{mg} / \mathrm{day}$ aspirin were subsequently given for 4 weeks; a $\beta$-blocker (initially metoprolol and thereafter sotalol) and pravastatin were added. Owing to gastrointestinal complaints, all other medications with the exception of sotalol were withdrawn. 16 months later, clopidogrel was given for a period of 63 days. 2 months after the start of medication, calf oedema was observed, which subsequently increased and led to withdrawal of the therapy.

At this time, the patient's bodyweight was $88 \mathrm{~kg}$. He presented with proteinuria of $11.5 \mathrm{~g} /$ day (non-selective, glomerular). Serum protein was about $45 \mathrm{~g} / \mathrm{L}$ with an albumin fraction of $20 \mathrm{~g} / \mathrm{L}$. The creatinine clearance was $106 \mathrm{~mL} / \mathrm{min}$ per $1.73 \mathrm{~m}^{2}$ and serum creatinine was $79.56 \mu \mathrm{mol} / \mathrm{L}$. Antinuclear antibodies, antineutrophil cytoplasmic antibodies, glomerular basement membrane antibodies, and direct Coombs' test were all negative. The IgE concentration was raised at $140 \mathrm{U} / \mathrm{mL}$. T he differential blood count did not show any abnormalities. Serum cholesterol was $12.93 \mathrm{mmol} / \mathrm{L}$.

U Itrasonography of the kidneys and the other upper abdominal organs did not show any abnormalities. There was no indication of a tumour or an infection, and the chest radiograph was normal. $\mathrm{H}$ istological investigation of a kidneypuncture led to the diagnosis of a stage II membranous nephropathy without glomerular or tubulointerstitial scarring (figure). In the follow-up period, proteinuria of more than 10 $\mathrm{g} /$ day persisted despite use of $100 \mathrm{mg} /$ day prednisolone with gradual dose reduction over 4 weeks. In addition, piretanide, nadroparin, pantoprazole, and, starting at day 30 of treatment, $5 \mathrm{mg} /$ day ramipril, were also given. Bodyweight was constant, and the oedema not very pronounced. Blood pressure was about 140/90 $\mathrm{mm} \mathrm{H} \mathrm{g}$.

M embranous nephropathy is the major cause of nephrotic syndrome in adults, and, in $62-86 \%$ of cases, it is idiopathic. D rugs are the most frequent cause of secondary forms. The manifestation of nephrotic syndrome 2 months after the start of clopidogrel treatment in the case described here may

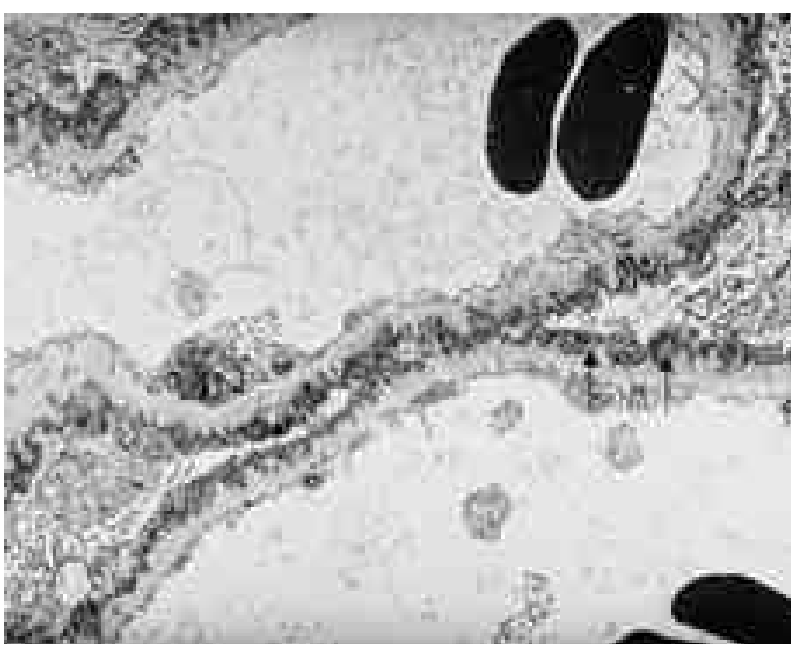

Glomerular-capillary walls with electron-dense subepithelial deposits, partially surrounded by basement-membrane material Transmission electron micrograph, magnification $\times 8900$. 